\title{
La poètica de la mort en la poesia catalana dels segles XVII i XVIII
}

\section{Death poetics in 17 th and 18 th Century Catalan poetry}

\author{
JOSÉ A. ORTIZ GARCÍA \\ joseaortiz50@yahoo.es
}

Universitat de Barcelona

\begin{abstract}
Resum: L'objectiu d'aquest estudi és proposar una visió sobre el tòpic de la mort en la poesia catalana pels segles XVII i XVIII. El punt central és la projecció pública de les composicions poètiques, tot apropant-nos a la literatura des d'un punt de vista cultural per presentar certs aspectes d'un tema clau en l'art barroc: el final de la vida. La primera part del text introdueix dos dels escriptors del barroc català, Francesc Fontanella i Agustí Eura. La segona secció recerca l'ús de la poesia catalana en les exèquies reials al voltant de la figura del monarca hispànic Carles II. Un cop presentades públicament les poesies en 1701, les edicions impreses són les que ens permeten una lectura contemporània. Publicacions d'altres gèneres poètics són la darrera part de l'article. Els Desenganys de l'Apocalipsi és una coneguda obra barrejant poesia i imatges amb una vessant didàctica per explicar el purgatori, l'infern, la glòria i el paradís als fidels lectors.
\end{abstract}

Paraules clau: mort, poesia, barroc, exèquies

Abstract: The aim of this study is a global vision about the topic of death in Catalan poetry throughout the 17 th and 18th centuries. Focusing on the public use of poetical compositions, we want to approach literature from a cultural point of view in order to present some aspects about a typical subject in baroque art: the end of life. The first part of the text introduces two main Catalan baroque writers, Francesc Fontanella and Agustí Eura. Moving to the second section, the paper researches the use of poetry in royal obsequies around the figure of the Spanish monarch Charles the Second. After the public presentation of the texts in 1701, the printed publication of them is how we can still read them. The printed copies for other kind of poetry creations is the last part of this article. Desengamys de l'Apocalipsi is a well-known text mixing poetry and images with a didactical purpose: to explain the Purgatory, the Hell, the Glory and the Heaven to faithful readers.

Keywords: death, poetry, baroque, obsequies 
La literatura s'ha ocupat de la mort com un dels seus temes cabdals. Els llibres condensen a les seves pàgines la pèrdua $\mathrm{i}$ el desengany de la vida: l'efímer de l'existència $\mathrm{i}$ el traspàs vers altres paradisos allunyats dels terrenals. Els llibres com a objectes també es materialitzen en l'escultura funerària. Les sepultures tardo-medievals i la tradició renaixentista presenten sovint figures jacents o mig jacents que tenen en les seves mans un o diversos llibres. Aquesta presència de la saviesa religiosa medieval continguda en els llibres donarà pas a una saviesa de caràcter humanista quan els títols de les obres presentades remetin a la nova mentalitat pròpia del quattrocento italià. Aquest recurs simbòlic del llibre té diverses vessants, per una part és la codificació del coneixement del finat, però també és una mostra de la seva espiritualitat i, nogensmenys, de la seva vida cultural. El llibre és, a més a més, un element de prestigi, de classe social que queda present en el repòs etern.

Aquests llibres els trobem també en la pintura, en les taules de l'evanescència, les natures mortes on apareixen apilats entre flors, cranis, rellotges i altres símbols de la caducitat de la vida. Aquest discurs que Bialostocki (1988) desenvolupa ens ofereix una mirada al llibre com objecte que cosifica la literatura i que lliga amb contextos funeraris o iconografies de les vanitas.

En la literatura dels segles XVII i XVIII, la mort esdevé protagonista. La literatura barroca està marcada pel desencís, l'escepticisme, l'excés i l'engany dels sentits. En un context global de desencant i desengany, no ha d'estranyar que els temes de poesia, teatre i prosa oscil lin entre la variabilitat de la fortuna, el món com un teatre, la vida com un somni, la fugacitat de la vida i la presència de la mort, que desemboquen en una vanitas literària que enllaça plenament amb altres manifestacions artístiques com gravat, pintura o escultura. Recursos retòrics, sintàctics i formals, com l'artifici i la desmesura, la paradoxa i l'antítesi, el contrast i l'enginy, són els mecanismes literaris que permeten evocar un món que té una mirada pessimista i que es replanteja el lloc de l'ésser humà en els designis del cel.

Partint d'aquestes idees ens proposem fer un recull d'exemples literaris en llengua catalana que pels segles XVII i XVIII han parlat de mort. Centrarem el nostre interès en la poesia amb un caràcter públic, és a dir, aquelles composicions que tenien una projecció social i a través de les seves lletres arribaven a la societat amb motiu dels funerals, les exèquies, els panegírics, la didàctica del macabre $\mathrm{o}$ altres formes literàries associades. El primer apartat versa sobre les figures de Francesc Fontanella i Agustí Eura. Analitzades algunes de les seves composicions, continuarem amb el segon apartat centrat en l'ús poètic del català en les cerimònies funeràries que arriben a nosaltres a través de les edicions impreses. Per finalitzar, una mirada a altres gèneres poètics ens permetrà copsar l'ampli espectre de la poètica de la mort. 


\section{Dos autors de la poètica de la mort: Francesc Fontanella i Agustí Eura}

De la mateixa manera que es fa en les literatures europees, podem parlar d'un «desengany català» com a tendència poètica. Si prenem els títols d'algunes composicions, recopilades a l'antologia de poesia catalana barroca de Rossich i Valsalobre (2006), ens trobem amb un panorama on la vida és vista com una aparença, una falsedat que desemboca en una mentalitat dirigida a les darreries de l'home: Al desengany del món i ses vanitats d'Antoni Massanés (?-1634), A un meravellós somni $i$ al desengany del món de Joan Terré (s. XVII), En les congoixes de la mort, lo que diu un fel contrit a un crucifix de Rafael Nogués (s. XVII), Sonet en menyspreu del Dimoni. Com se li escapen les ànimes dels Confrares del Carme de Josep Elies Estrugós (?-1645), o A l'engany del món de Rafael Cordelles (s. XVII), entre d'altres.

$\mathrm{El}$ «desengany català» troba en tres figures literàries un complement a les mostres esmentades: Francesc Vicent Garcia (1578/79-1623), Francesc Fontanella (1622-1682/83) i Agustí Eura (16841763). Els tres creadors, per la qualitat de la seva obra i per la seva cronologia, ens permeten desenvolupar una visió de la literatura barroca des dels inicis del segle XVII fins al segle XVIII.

Francesc Vicent Garcia, conegut com el Rector de Vallfogona, és un dels primers exponents de la poesia barroca catalana, que oscil la entre la producció culta de sermons funeraris i composicions poètiques sobre el desengany del món com $A$ la vanitat del món $i$ engany, o de caràcter burlesc, com per exemple Epitafi a un gran bevedor d'aiguardent, lo qual morí de gota. De l'autor, donada la projecció social de la composició, destaquem el Sermo predicat en la iglesia cathredral de Gerona, en les exequies fetes a sa Magestat Catholica del Rey Don Phelip Tercer nostre Senyor, lo dia 12 de Maig 1621, editat a Barcelona per Jeroni Margarit l'any 1622. Amb motiu de les exèquies gironines de Felip III l'any 1621, el rector de Vallfogona elaborà un sermó en prosa castellana amb al lusions i referències a l'auctoritas dels autors clàssics i dels passatges bíblics.

Si centrem la recerca en els exemples poètics en llengua catalana amb una funció pública, són dues les figures, Francesc Fontanella i Agustí Eura, que ens donen una visió més àmplia del tema que tractem. Fontanella, plenament situat en el segle XVII, és potser un dels millors exemples escrits per desenvolupar una teoria de la vanitas literària catalana (Miró 1995, 1998; Valsalobre / Miralles / Rossich 2015). ${ }^{1}$ Composicions poètiques com $A$ la mort de Nise, A una calavera $i$ rellotge de pols o Desengany del món són exemplars pel que fa a l'ús dels recursos literaris barrocs per ocupar-se del tema de la vanitas. En aquest darrer, Fontanella desenvolupa els temes literaris del pas del temps, la fugacitat de la vida en mans de l'inexorable tempus fugit, la pèrdua de la bellesa, que mostra a través d'al lusions florals o de topoi com serien el naufragi, la nit, les ombres, o la vida que transcorre com un riu. El pessimisme davant la vanitat del món porta l'autor a mostrar una imatge desencantada

1 Una eina de gran ajuda per la investigació és la plataforma digital NISE amb la seva base de dades i la biblioteca digital. Destaquem la secció dedicada a l'obra poètica completa de l'autor que tractem, coordinada per P. Valsalobre i M. Sogues (2017) consultable en xarxa a http://www.nise.cat/BibliotecaDigital/Autors/FrancescFontanella.aspx. 
de l'existència on aparences i desmitificació del món esdevenen claus interpretatives de la temàtica supranacional del desengany, també present en la peça teatral Lo desengany.

De la producció poètica de Fontanella destinada a priori a una audiència, hem de fer-nos ressò dels seus vint-i-un emblemes fúnebres, sota l'encapçalament Poteris nec morte revelli, formats per la descripció de la pictura i la inscriptio en llatí. Manca la subscriptio o complement textual que acostuma a estar present en altres composicions que fan ús del llenguatge de l'emblemàtica. Estudiades aquestes composicions (Miró 1995; Bonaventura 2006; Bonaventura 2010) ens plantegen encara l'enigma del seu destinatari i com haurien estat presentades al públic. Malgrat que no es completin amb una versificació en forma d'epigrama, són força interessants com a mostra emblemàtica on la llengua catalana defineix la imatge que acompanyaria al text llatí que acostuma a referenciar l'auctoritas clàssica: Ovidi, Virgili o Torquato Tasso, entre d'altres. La divisió temàtica, la traducció i l'anàlisi literària que fa Bonaventura $(2006,2010)$, la podem completar amb un paral lelisme amb altres produccions que situen Fontanella en el zeitgeist del barroc peninsular. Podem analitzar alguns exemples.

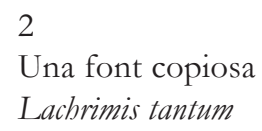

(Miró 1995: II, 170).

Aquest «Només amb llàgrimes» el podem relacionar amb l'Afflictio spiritus de les Empresas Morales de Juan de Borja (Vistarini 1999: 358-359) que utilitza la font com a emblema d'aflicció. També podríem fer un exercici similar amb el cinquè dels emblemes fontanellans.

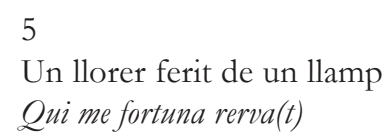

(Miró 1995: II, 170).

El caràcter profètic del llorer, dedicat al Déu Apol lo, divinitat dels que veuen el futur, es posa en contacte amb la protecció del llorer davant el llamp. En aquest cas el que albirem del futur és la ferida com a designi de mort. La tradició cultural del tema es relaciona amb Alciato i el Laurus del seu llibre Emblemes (Vistarini 1999: 470-471). Referències al caràcter funerari de les composicions serien, entre d'altres, les palmes de la glòria o lloança del traspassat i la nau del naufragi.

18

La xifra entre palmes y flors

Semper honos nomenque tuum laudesque manebunt. (Aeneid. I, 609)

(Miró 1995: II, 172) 
19

Una nau en naufragi

Coelo nimium confisa sereno. (Aeneid. I, 870)

(Miró 1995: II, 173)

La xifra, o les inicials del nom entre palmes i flors, evoquen la glòria del personatge. Per Fontanella «Sempre duraran la teva glòria, el teu nom i les teves lloances» $\mathrm{i}$ Juan de Borja ho referencia amb l'honor i la virtut a les Empresas Morales: «Ninguna duda ay, en que siempre fue, y ha sido la bonra, la cosa más estimada (...)» (Vistarini 1999: 605). La glòria de la memòria del divuitè emblema ens porta al naufragi de la nau del dinovè: «Massa t’has refiat de la serenor del cel». Sebastián de Covarrubias Horozco als seus Emblemas Morales ens evoca la nau naufragada a Fortuna in porto com a derivació de La Vita Fuge de Francesco Petrarca (Vistarini 1999: 565). La calma enganyosa de la mar ens fa confiar-nos i la nau no arriba a bon port, la vigilància constant és la clau vital que es desprèn de les composicions de Fontanella i Covarrubias.

Marcat per la Guerra dels Segadors, conflicte en el qual lluità i fou superintendent d'artilleria a la batalla de Montjuïc l'any 1641, Fontanella és també un dels encarregats d'exaltar la figura de Pau Claris i Casademunt (1586-1641) en el panegíric Occident, eclipse, obscuredat, funeral, aurora, claredat, belleza, gloriosa al sol, lluna y estela radiant de la esfera, del epicle, del firmament de Cathalunya:panegirica alabanca, en lo vitim vale, als manes vencedors del doctor Pau Claris publicada a Barcelona per Gabriel Nogués l'any 1641 (Fontanella 1641). Disposem d'exemplars conservats a la Biblioteca de Catalunya (F. Bon. 7614 i 19655/13) als que podem afegir l'edició crítica moderna del text (Clarasó / Miró 2008). Presenta Fontanella al diputat com a invencible: «O Claris noble, o vencedor invicte, o Atleta feliz, Llibertador y Pare de la Pàtria fortunada més per filla de vostre valon». El text utilitza la iconografia astral lligada als tòpics barrocs amb l'escut familiar amb lluna i estrella. D'aquesta manera, Claris és el sol i la mort és la nit; es tracta, doncs, d'una iconografia celeste aplicada al traspàs del poder. Fontanella combina prosa i poesia per fer un exercici trilingüe de virtuosisme literari per homenatjar la memòria del personatge. Per la seva banda, Gaspar Sala i Berart (1605-1670) descriu aquest mateix cerimonial en el qual va ser l'orador a Lagrimas catalanas al entierro y obsequias del deputado ecclesiastico de Cataluña, Pablo Claris, publicat a Barcelona per Gabriel Nogués l'any 1641 (Sala i Berart 1641). Edicions conservades del text es troben a la Biblioteca de Catalunya (F. Bon. 2124, 6199 i 19655/10).

Sobre les composicions poètiques de Fontanella, represes per Miró (1995), Bonaventura (2006), Clarasó i Miró (2008), Alegret (2009), Clarasó (2009) i Bonaventura (2010), voldríem destacar l'estructura interna del text, prosa i poesia intercalades, a través de les referències astrals com a eix temàtic vertebrador: el sol com a símbol de les seves virtuts i la lluna i les estrelles com a part de la seva heràldica familiar. Estableix Fontanella referències visuals directes com amb la pictura amb el sol, la lluna i les estrelles, acompanyada del motto «Ego meis praeluxì que és preludi de l'epigrama «Sepulta Phebo sa claror divina». 


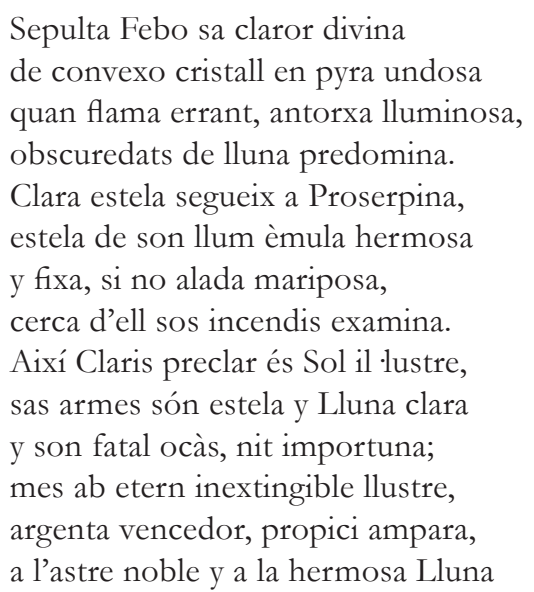

(Clarasó / Miró 2008: 90)

Altres composicions poètiques van intercalant-se amb la prosa. Voldríem destacar la que porta per primer vers «Phènix que, animat a incendis». Fènix, àliga i serp són els trofeus al legòrics del Sol (en referència a Pau Claris) per les simbologies associades a cada animal. Aquesta reminiscència dels bestiaris medievals forma part d'un recurs cultural que Fontanella utilitza: el fènix com a renaixement, l'àliga altiva envolada cap al cel i la serp que muda pell. La transposició de Sol-Claris es completa lligant aquestes idees amb els elements celestials vertebradors de tot el discurs: el renaixement del fènix/Sol; el cel de l’àliga/Horitzó; i la regeneració de la serp/Aurora.

\footnotetext{
Phènix que, animat a incendis, mort y viu en si mateix, ab urna y braçol sabeo jau cendra i renaix ocell. Àguila, que 1 llarc marfil en penya inculta rompent, ab joventut generosa bol recupera altaner. Serpent que en líbica cova dexa la caduca pell ostentant-se ab colors novas iris rèptil del desert, tropheos són al legòrichs del Sol que, ab ardor excels, en lo occident y la aurora és Phènix, Àguila y Serp. Y 1 Sol és tropheo a Claris Que, ab lo mortal occident, en aurora celestial renaix a orizont etern.
} 


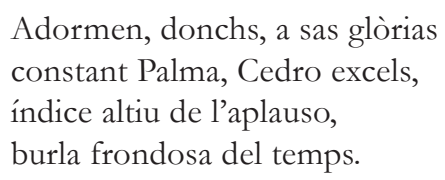

(Clarasó / Miró 2008: 93)

Com a darrera menció a la producció fontanellana amb motiu de la mort de Pau Claris, «Torre excelsa, alta atalaia» és una de les composicions més conegudes. Com a lloança a la fortificació de Montjuïc pel paper defensiu, amb la seva torre de guaita, que va exercir per a la ciutat de Barcelona durant la guerra dels Segadors, ens aporta una imatge urbana en temps de conflicte.

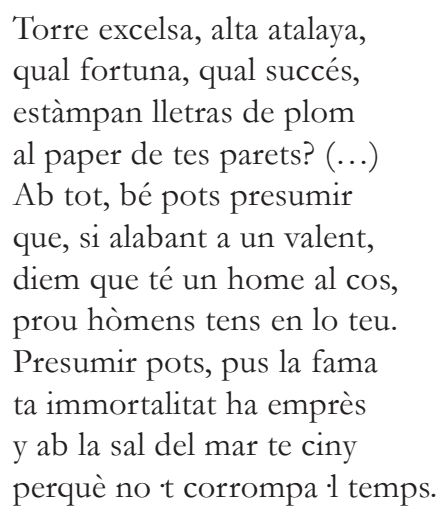

(Clarasó / Miró 2008: 109-110)

A continuació parlarem de la producció de l'autor Agustí Eura, immersa en la mentalitat i l'estètica barroca en ple segle XVIII. Monjo de l'ordre dels agustins, prior a Girona i Barcelona i bisbe a Ourense en època de Felip V, és, a més a més, un literat que conrearà el camp de la poesia religiosa, mística i ascètica basada en el menyspreu del món. Entre les seves composicions destaquem Poesia sacra per les agonies de la mort, La mort suavisada, En memòria de la sepultura i Anatomia mental del cos humà (Valsalobre 2002: 195-302). La producció amb un estil directe que interpel la l'espectador, a mig camí entre el sermó i la reflexió espiritual, pren una volada que ens fa pensar en una derivació pública de les idees religioses. Per aquest motiu el recollim en el nostre text donada aquesta vessant que implica directament l'espectador en la seva poesia ascètica. ${ }^{2}$

La temàtica tractada per Eura enllaça amb els manuals dels ars moriendi i amb la composició de lloc jesuïta. Les seves interpel lacions al lector són mecanismes literaris de conscienciació de la

2 Valsalobre ja ens indica que els quatre poemes «es difonen manuscrits d'una manera més o menys conjunta» (Valsalobre 2002: 62). Enteses com aplec poètic de tema macabre i difoses com a conjunt, ens reafirma la projecció pública de les poesies defensada. 
pròpia mort i de la construcció mental d'aquesta, seguint la tradició de la poesia ascètica castellana i els exercicis espirituals. La seva aproximació a la mort és interior, amb l'esquelet i la calavera com a símbols pedagògics de renúncia i reflexió sobre la mort, que enllaça amb la seva relació amb la congregació barcelonina de la Bona Mort del convent agustinià de la ciutat. Valsalobre ens especifica que «la mort en la poesia d'Eura és “macabra, omnipresent, moralitzant”, però és del tot exempta d'altres característiques de la mort barroca; "aparato y cerimonial"» (2002: 64-65). El missatge de vanitas queda, així doncs, vehiculat a través d'un missatge moral del memento mori que recupera la tradició medieval de les danses macabres, on vida i mort estan presents en l'imaginari del fidel-lector (Valsalobre 1989).

Una referència directa a la pèrdua de l'alè de vida és el poema Anatomia mental, un repàs a l'anatomia humana evocant la pèrdua dels sentits i descrivint com eren les parts del cos que ara l'autor presenta mortes, quietes, sense vida. El crani és descrit com a memento o recordatori de la mort més enllà de l'intel lecte que hauria engendrat en vida:

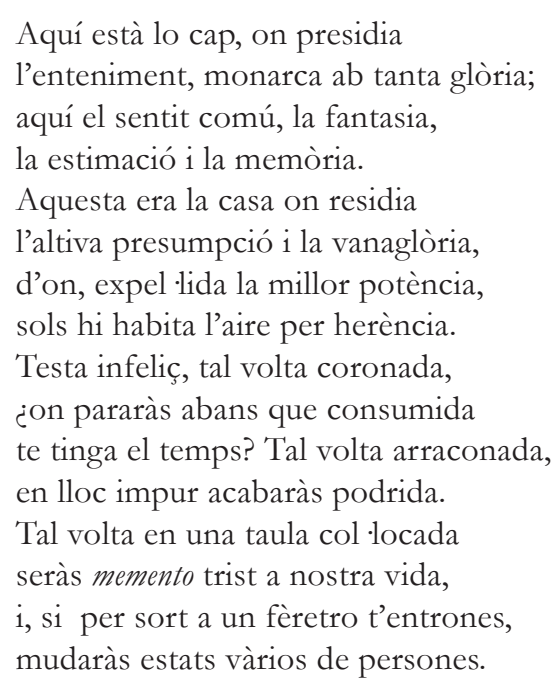

(Valsalobre 2002: 285-286)

La poesia d'Eura incorpora la qüestió visual, la instrucció de la mirada, utilitzant el recurs retòric de la hipotiposi, per implicar el receptor del seu missatge, tal i com podem llegir a Anatomia mental: «Mira i repara / les cendres que est cadàver vui en dia» (Valsalobre 2002: 292); o En memòria de la sepultura: «Mira-la bé, mortal, que deus mirar-la, / casa que tant de temps has d'habitar-la» (Valsalobre 2002: 254). La mirada esdevé d'aquesta manera la forma de combatre la ceguesa de la vanitat del món, l'engany de la mort amb fórmules literàries directes que Eura utilitza i que defineixen la seva poesia, en aquest cas per deslliurar el mort de la sumptuositat de la sepultura, que seria una mostra de vanitat i supèrbia. 
La composició catalana En memòria de la sepultura, es vincularia directament amb alguns dels exemples literaris hispànics, com podria ser el Discurso de la verdad de Miguel de Mañara. Tant Eura com Mañara, ens presenten la imatge crua del sepulcre habitat pel cadàver:

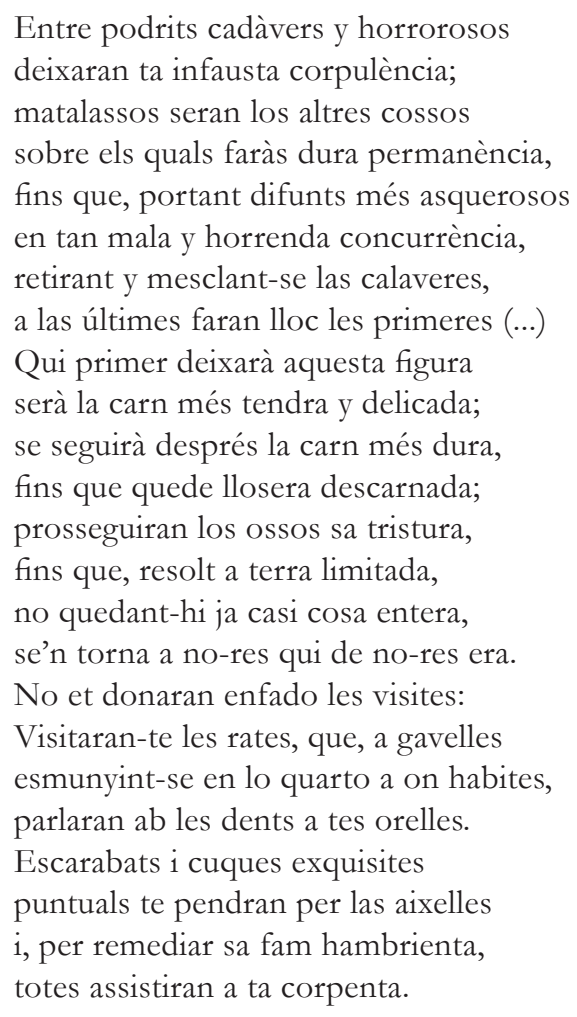

(Valsalobre 2002: 266-269)

La pròpia mort d'Agustí Eura va ser exaltada per part del convent agustinià de Barcelona en el panegíric ofert amb motiu dels seus funerals. L'autor que evocava la mort va rebre oracions per la seva memòria un cop va superar el llindar de la vida. El text escrit, basat en la predicació funerària d'Armanyà Oracion e inscripciones en las sumptuosas exequias que el Convento del P.S. Agustin de Barcelona dedicó en su real templo a la pia memoria de Fr. Agustin de Eura: en los dias 29 y 30 de enero de 1764, és una mostra del reconeixement i fama que va adquirir Eura (Armanyà 1764).

\section{Les edicions impreses de les exèquies: a l'entorn de Carles II}

La projecció pública de les composicions poètiques té en les edicions impreses un exemple clar de la voluntat de mantenir el record de l'efímer per a la posteritat. Les creacions amb un motiu funerari adquireixen així un rang de difusió i de permanència. La poesia civil esdevé també una eina 
de propaganda política, quan es dedica al monarca i es creen unes afiliacions que tenen, en la lletra impresa, un sistema de propagació dels posicionaments àulics (Pérez Samper 1989). L'any 1701 té lloc la mort del monarca Carles II. Les mostres barcelonines per la pèrdua del fill de Mariana d’Àustria i hereu de la corona a la mort de Felip IV són testimoni històric de les accions públiques portades a terme en el moment final de la seva vida. Les exèquies de la ciutat comtal ens han deixat dues mostres impreses de gran riquesa per l'estudi de les relacions de successos i de la literatura poètica vinculada a l'àmbit funerari. Aquests dos exemplars, estudiats per Galindo (1991) i Ortiz (2014) són el de Josep Rocabertí, Lagrimas amantes de la Excelentissima ciudad de Barcelona: con que, agradecida a las reales finezas y beneficios, demuestra su amor y su dolor en las magnificas exequias que celebrò á las amadas y venerables memorias de su difunto rey y señor don Carlos II, editat a Barcelona per Juan Pablo Martí (Rocabertí 1701); i el dels membres de l'Acadèmia dels Desconfiats, Nenias reales y lagrimas obsequiosas que a la immortal memoria del gran Carlos Segundo en credito de su mas imponderable dolor y desempeño de su mayor fineza dedica y consagra la Academia de los desconfiados de Barcelona imprès a Barcelona per Rafael Figueró (Nenias reales... 1701).

Lagrimas amantes... ha estat una publicació analitzada atenent als cal ligrames que presenta i a les referències al funeral reial, sobretot per afegir, al text, la imatge gravada del túmul aixecat a la catedral de Barcelona en memòria de Carles II. Els cal ligrames evoquen amb la seva tipografia creus, túmuls, escuts i pires funeràries. La paraula queda supeditada a la visualitat de la forma que composen i que ens transporta a exercicis tipogràfics de gran riquesa simbòlica. Aquestes composicions reforcen el missatge del text $\mathrm{i}$ aporten a les edicions lligades a les exèquies un component creatiu que tindrà una repercussió en el món impressor del barroc català. Entre els inclosos a l'edició comentada, destaquem el realitzat per Pere Màrtir Castells i Badia en forma de creu i dos canelobres, el de Josep Campins i Aran o el de Josep de Rocabertí i de Llupià, ambdós en forma de túmul, tots ells en llengua llatina. El tercer cal ligrama és signat també per «Franciscus Barnola Typographité, exculpsit Barcinone, Anno M.DCCI», signatura insòlita de l'impressor, donada la complexitat d'aquesta tipologia de peces.

A nivell literari ens trobem amb variades composicions en castellà, llatí i català. Els Hieroglifichs, y Poesias en català (Rocabertí 1701: 181-187) sumen un total d'onze. La descripció de la imatge, el lema i la poesia ens tornen a endinsar en el camp de l'emblemàtica en llengua catalana, completant els que anteriorment hem comentat parlant de Francesc Fontanella. En aquesta ocasió, són diferents els autors que proposen cadascuna de les onze combinacions, algunes d'elles imagotextuals. Malauradament la part gràfica no ha estat conservada i disposem només de la descripció per poder treballar.

L'imaginari emblemàtic reprèn les temàtiques d'ús habitual amb motiu d'unes exèquies. La primera ens evoca a la pictura una candela apagada i un raig del cel que l'encenia. Com a inscriptio trobem Lumen de lumine, i la subscriptio signada per Agustí Rovira diu: 
La llum que antes mantenia, qualsevol la apagarà; pero aquesta no podrà.

(Rocabertí 1701: 181)

El rei és la llum que no s'extingeix mantenint aquest doble binomi vida-llum/mort-foscor que és un dels topoi de tradició funerària. La segona mostraria «(...) una Esfera, y baix de ella un Sol que cau perpendicularment sobre un tumol Coronat». El lema Iam labentibus annis es completa amb:

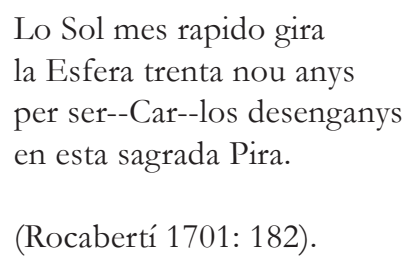

Segueixen, a aquests dos jeroglífics de fons emblemàtic, poesies, ja siguin glosa, sonet, quintilla o dècima. Als recursos literaris i a la mètrica hem d'afegir la riquesa d'estratègies textuals que aporten varietat. La vuitena es presenta així:

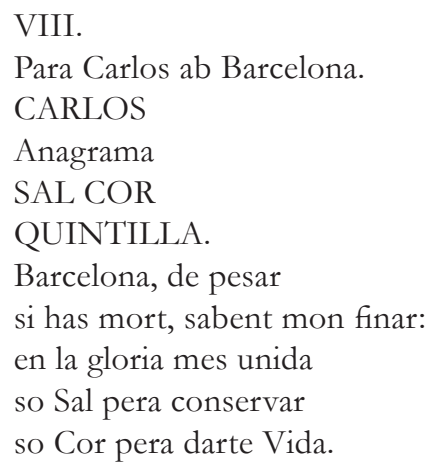

(Rocabertí 1701: 186)

Prenen el nom del rei i amb l'anagrama SAL COR creen una referència poètica, la sal que conserva i el cor de la vida, com es fa també a la desena composició signada per Bonaventura Figarola que utilitza CAR SOL. En aquesta és Barcelona com a personificació qui parla vessant llàgrimes per la pèrdua de llum del sol, l'eclipsi, on Carles és el SOL de l'anagrama construit: 


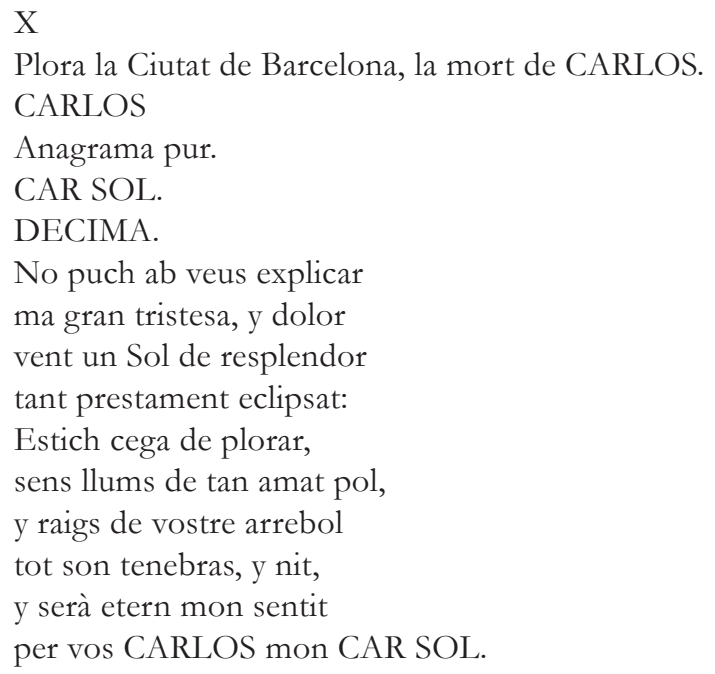

(Rocabertí 1701: 186-187)

A l'altra publicació, les Nenias reales..., els membres de l'Acadèmia dels Desconfiats presenten elegies de la mà de Lorenzo de Barutell, Francesc Emmanuel de Vega, o Josep de Taverner entre d'altres. Aquesta publicació poètica esdevé una versió del gènere de les relacions de successos a través de les dedicatòries literàries amb motiu de la pèrdua del monarca:

\footnotetext{
Y la que sabe quanto es Barcelona acreedora à tus Reales Munificiencias, ayuda à su Patria à llorar tu falta, haziendo eco à su agradecimiento (...) Y estos sudores Academicos, que como feudo desigual à merito tan Augusto, tributamos Desconfiados à tu celebridad, fiarán à solo este favor acreditar por sacrificio la fineza, por holocausto la voluntad, por ofrenda el voto, por paga el deseo, por desempeño el cariño, y por vale lo inmortal (Nenias reales... 1701: III-IV).
}

Aquesta és la primera manifestació pública draquesta acadèmia en lyambient disincertesa per la mort de Carles II, un grup derudits que volien fomentar una cultura delit. Cal destacar la presa de posició política que va suposar aquesta iniciativa ja que una part important dels membres eren austriacistes que es lligaven a la línia successòria dels Habsburg. En aquest sentit podem entreveure una primera forma d'oposició a l'aposta per la línia dels Borbó i un posicionament estratègic per part de la identitat catalana que es va mantenir en la Guerra de Successió.

Francesc Gazan ens proposa en la portada un recull del tòpic de l'emblemàtica del naufragi com a final de la vida però amb una embarcació en el port, l'esperança, sota el motto «Tuta quia diffidens» (Fig. 1). 


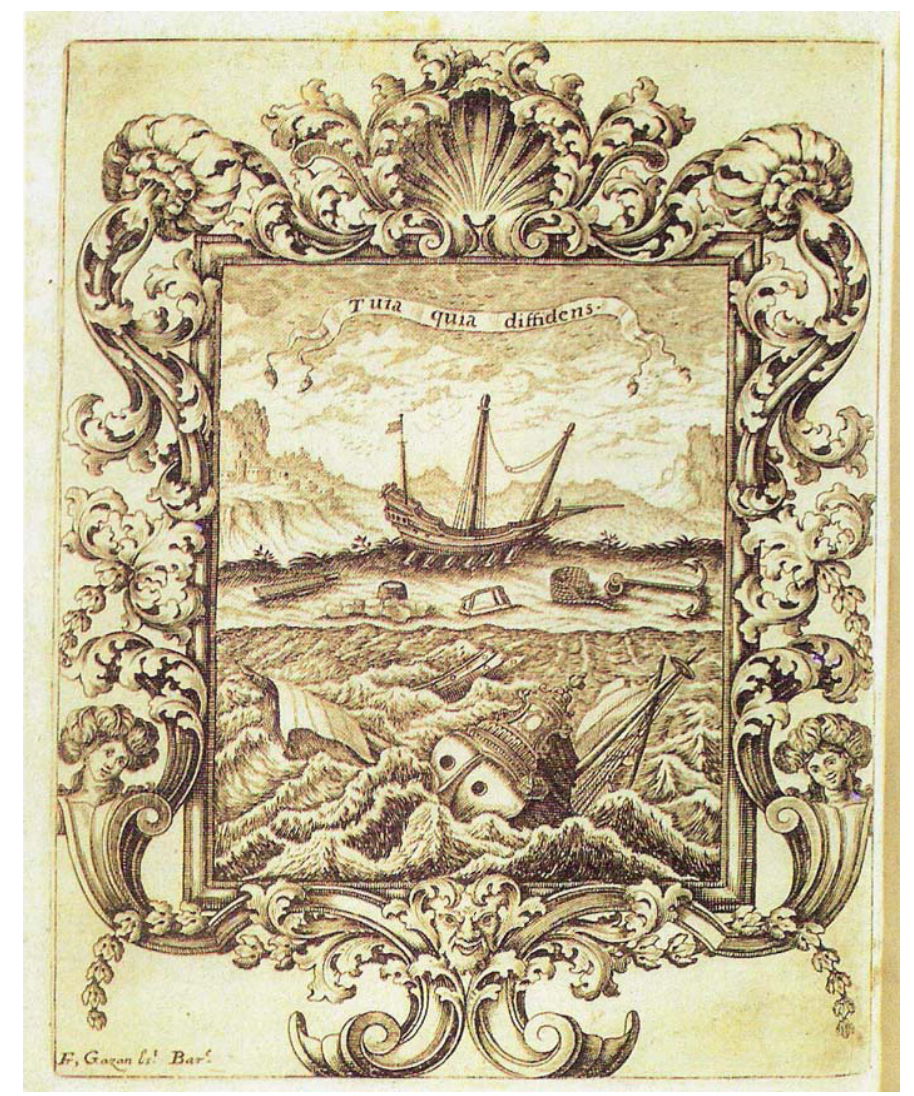

Fig. 1. Francesc Gazan, Portada de Nenias Reales... (1701).

Imatge i evocació literària ens simbolitza la confiança d'aquests intel lectuals en navegar amb seguretat quan passi la tempesta. Com a constant en la cultura visual occidental, el naufragi ha estat imatge de ressò moral, polític o religiós. Per Alciato l'esperança és un vaixell ancorat. El bon governant és el pilot que evita el naufragi, per Diego Saavedra Fajardo, i fins i tot l'Església pot ser mostrada com a nau en l'ambient contrareformista. La polisèmia de la imatge arriba a Francesc Gazan qui es fa ressò de l'ambient culte que fomentava l'Acadèmia dels Desconfiats. El gravador transmet el concepte «Segura, perquè desconfia» amb el vaixell a la riba, que els acadèmics expliquen a la Razon de la Obra, dins la primera part de les Nenias reales...:

«Se resolvio erigirla no sin desconfiança, cada qual de sus talentos, dandole esta el nombre de Academia de los Desconfiados, y tomando por Empressa la de un Mar embravecido, en quien se miran, lastimoso triumpho del Hado, y la Inconstancia derrotados fragmentos de una Nave, que ha naufragado, y un Barquillo desarmado en la arena con el lema "Tuta, quia diffidens"》 (1701: XX).

Entre les creacions poètiques trobem sonets acròstics i cal ligrames que ens situen en les fites topogràfiques de la cultura impresa catalana barroca. Combinant el castellà, el llatí i el català, cada 
acadèmic dedica un discurs en prosa o una composició poètica de mètrica i estructura variada entre les que trobem: sonet, octava, romanç hendecasíl lab, redondilla o glossa, entre d'altres. S'intercalen, a més a més, anagrames, epigrames i altres creacions que prenen un paper protagonista en editarles com a desplegables entre les pàgines de l'edició impresa. En un d'aquests desplegables apareix una composició llatina que introdueix la lletra de mirall amb el motto "Quis jacet hic? CAROLUS: quid faris? falleris hocce: Non jacet hic CAROLUS; sed jacet Hesperia» (Nenias reales... 1701: intercalat 92-93). Un altre exemple, aquest en llengua catalana, utilitza la tipografia en diagonal a manera de sonet en forma de laberint: Catalunya com a dama reclinada en el sepulcre lloant al monarca usant «DON CARLOS SEGON» com a base per a l'epitafi (Nenias reales... 1701: intercalat 100-101) (Fig. 2).

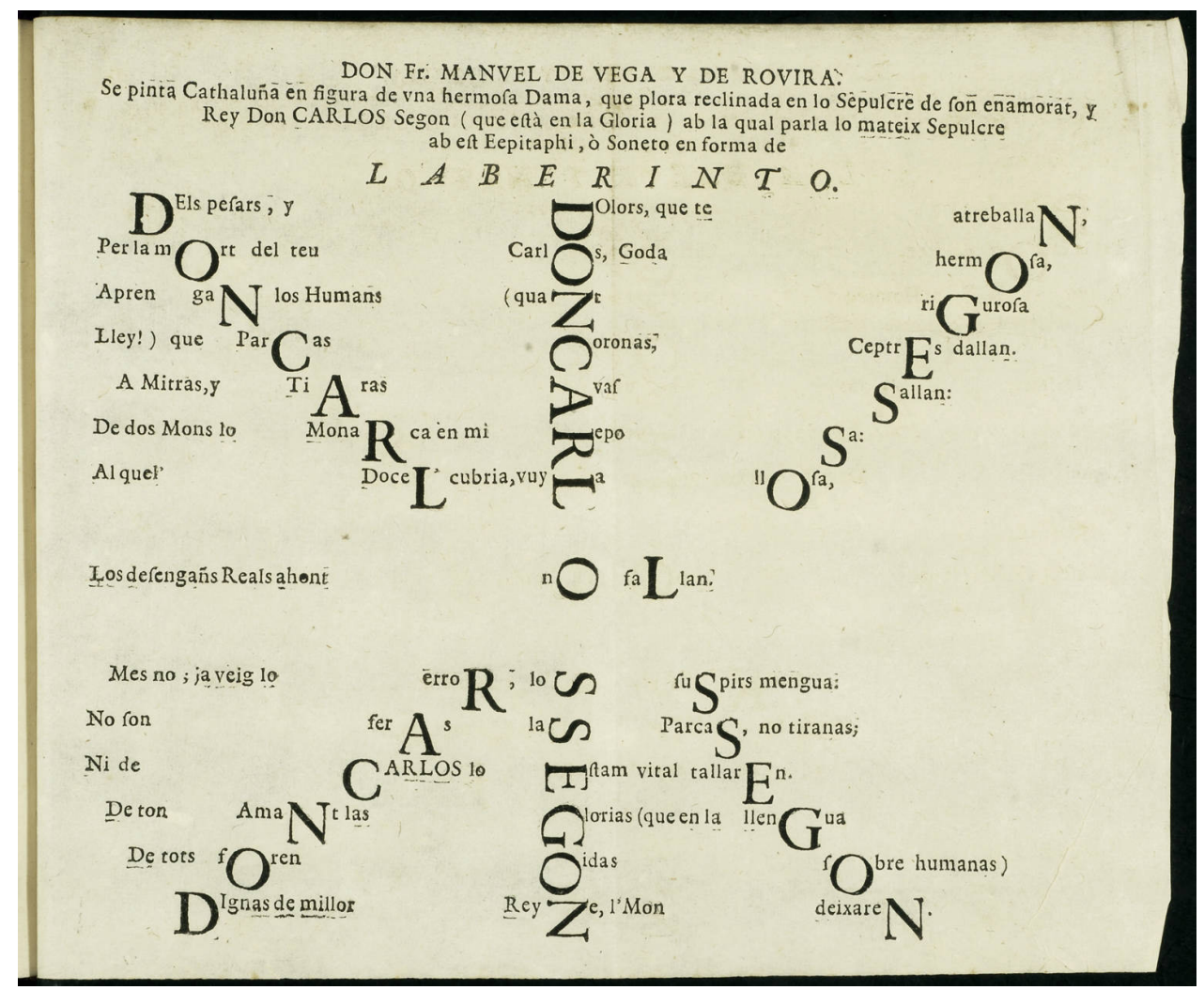

Fig. 2. Cal ligrama en memòria del monarca Carles II (Nenias Reales..., 1701).

Si reconstruïm el sonet respectant la grafia i puntuació originals, però reprenent les majúscules del laberint en minúscules, podem llegir:

Dels pecats, y dolors, que te atreballan,

Per la mort del teu Carlos, Goda hermosa,

Aprengan los Humans (quant rigurosa

Lley!) que Parcas Coronas, Ceptres dallan. 
A Mitras, y Tiaras avasallan:

De dos Mons lo Monarca en mi reposa:

Al quel Docel cubria, vuy la llosa,

Los desenganys Reals ahont no fallan.

Mes no, ja veig lo error, lo suspirs mengua:

No son feres las Parcas, no tiranas;

Ni de Carlos lo estam vital tallaren.

De ton amant las glorias (que en la llengua

De tots foren oidas sobre humanas)

Dignes de millor Rey nel mon deixaren

(Nenias reales... 1701: intercalat 100-101).

Temàticament, l'autor, Francesc Manuel de Vega i de Rovira, ens ofereix una reflexió sobre la vanitat terrenal. ${ }^{3} \mathrm{La}$ mort no entén de poders: les corones, ceptres, mitres i tiares són dominades per les Parques. Aquell que sota pal li anava ara sota una llosa sepulcral es troba. D'ell ens queden les seves glòries com a llegat del seu regnat.

Altres sonets serien els de Josep Amat, secretari de l'Acadèmia, Fonch nostre Rey nostre major Amant, i el d'Anton de Paguera La filal de Agenor plora oportuna. Aquest darrer també escriu un romanç heroic, Ab llagrimas de sanch trista, y confusa. Josep Clua en la seva glossa No del merit, ambiciós també fa ús del català, així com a la redondeta de tradició castellana:

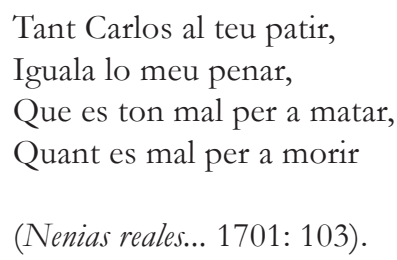

\section{Altres gèneres poètics}

Altres formes poètiques que volem analitzar en aquest text són les que presenten una voluntat didàctica per mostrar l'ésser humà en les seves acaballes. Magí Cases fou sacerdot i escriptor, catedràtic de retòrica de la Universitat de Barcelona. Entre la seva producció destaca Desenganys, introducció a la vida devota, clau del llibre escrit dintre i fora publicada a Barcelona l'any 1673 per Rafael Figueró. Coneguda amb el nom de les edicions posteriors, Desenganys de l'Apocalipsi, l’obra és una recreació poètica dels camins de l'eternitat: mort, judici, infern i glòria. Aquestes són les quatre bases de l'escatologia cristiana que donen les claus d'interpretació de la vida, la mort i el més enllà. ${ }^{4}$ L'èxit de la publicació, a través

3 L'autor, eclesiàstic i escriptor, membre de l'Acadèmia dels Desconfiats, hauria estat editor de les obres de Francesc Vicent Garcia, rector de Vallfogona.

4 Sobre aquestes quatre darreries, citem la pintura de El Bosco que les uneix, Taula dels pecats capitals, conservada al 
de les múltiples reedicions, radica en el fet de lligar text $i$ imatge amb els gravats que l'acompanyaven: un llibre d'exercicis per l'esperit devot que presenta una clau interpretativa de la paraula escrita amb les imatges. La part visual gravada esdevé quelcom més que una decoració per transformar-se en un element «articuladamente significante» citant a (Diez Borque 1993: 139). ${ }^{5}$ La concepció de l'autor lliga amb les predicacions i sermons de l'època. La literatura de rerefons religiós passa a un terreny civil per fer arribar les idees al públic destinatari. Les indulgències prèvies al text així ho expressen:

\begin{abstract}
Considerant quant importa la memòria dels Novissims, y Camins de la Eternitat, pera tenir plens los cors del sant Temor de Deu, y encesos en son amor; com pera aborrir lo camí del vici, y abraçar lo camí de la virtut en seguiment de Christo: Perçò encarregant als Pares ensenyen à los fills estos Desenganys; aixi mateix als Mestres los fassen llegir en las Escolas à los Deixebles, los concedeixen per cada vegada de tant saludable exercici, in forma Ecclesiae consueta (Cases 1974: 2).
\end{abstract}

Si prenem alguns fragments a tall d'exemple podem aprofundir en aquest text. ${ }^{6}$ La mort és inexorable però el moment de la seva arribada és una incògnita:
Lo morir es cosa certa,
solament la hora es incerta.
Qui a la Mort va caminant,
sab lo que te caminat:
mes no sab quant te distant
la Mort, y la Eternitat.
Un dia menys tens de vida
cada nit, si be hi tens compte;
y un dia mes que dar compte,
sempre incert de la partida.

(Cases 1974: 14-15)

Per Cases, el purgatori és una premsa de foc que hauria de ser un espant prou important per allunyar a l'ésser humà dels seus pecats. Forma part del judici entre advocat i fiscal, àngel i

\footnotetext{
Museo Nacional del Prado. Aquesta obra datada entre els anys 1490-1510 va ser adquirida pel monarca Felip II i enviada al Real Monasterio del Escorial l'any 1574. De l'àmplia bibliografia sobre el tema, citem l'article dels anys setanta sobre la peça (Gibson 1973) i el catàleg de la darrera gran mostra sobre el pintor (Silva 2016). Altres exemples podrien ser les versions gravades de Philipe Galle, Goltzius o Wierix, per citar alguns exemples europeus.
}

5 L'estudi visual dels gravats ha estat desenvolupat per Immaculada Socias en diversos estudis (Socias 1993a, 1993b). Així mateix, destaquem el darrer estudi sobre les fonts iconogràfiques i el context religiós a càrrec de S. Canalda (2016) i la presentació de les edicions de gran format (c. 1683-1780) de l'Arxiu Històric de Barcelona, dins de l'exposició temporal al Museu d'Història de Barcelona, Imatges per creure. Catòlics i protestants a Europa i Barcelona, segles XVI-XVIII, entre el 21 de juny de 2017 i el 14 de gener de 2018.

6 Utilitzem l'edició facsímil (Cases 1974) per la cita textual que recupera l'original sense datar (finals del segle XVII o inicis del segle XVIII) fet a Barcelona per Jaume Surià. 
dimoni, valorant les bones accions i els pecats en una psicòstasi que obre la via del Cel o la via de l'Infern. El camí de transició és el purgatori com espai de temporalitat breu on s'expurguen els pecats venials. L'anomenat tercer lloc el descriu així:

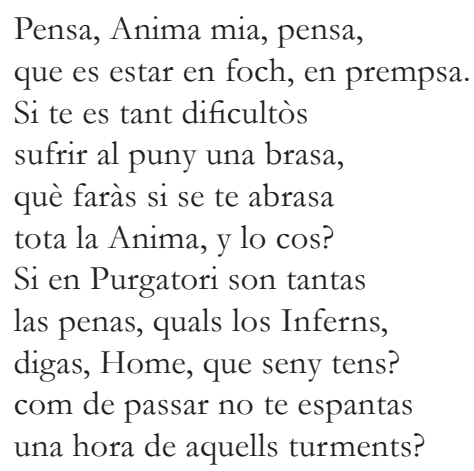

(Cases 1974: 33)

Aquesta visió divergeix de les més comunes que presenten les ànimes entre les flames del foc purificador. Aquesta és la visualitat comuna que transcendeix el temps i marca la iconografia lligada al purgatori. En canvi, en els gravats que il lustren la publicació de Cases o que deriven d'ella, és la premsa la mostra gràfica tal i com observem a la mostra textual. La violència dels càstigs es reserva per la compartimentació de les penes en les imatges de l'infern, un espai ordenat pel tipus de càstig físic o sensitiu amb una sentència inexorable:

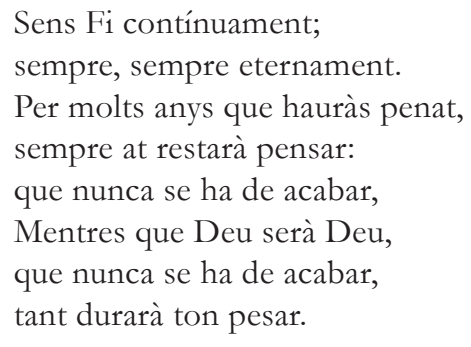

\section{Conclusió}

A tall de conclusió, la poètica de la mort en la poesia catalana pels segles XVII i XVIII té fonts variades. Analitzades en aquest article algunes d'elles, s'observa una tendència a la reflexió entorn el concepte de mort que es difon a través de diversos gèneres literaris. En biblioteques i arxius encara trobem material per aprofundir en l'estudi i aportar noves aproximacions en un futur. Composicions 
aillades de Fontanella o d'Eura ens han mostrat la concepció de la vanitas en un àmbit escrit. Incorporades a les exèquies, com a part de la festa efímera funerària, tenen una individualitat en fer referència al cadàver honrat en elles. Hem desenvolupat els casos de Pau Claris i de Carles II com a dos mostres simptomàtiques de la producció del període. Altres gèneres, de major grau de projecció dins de la societat, ho mantenen amb una vessant didàctica i de predicació com analitzàvem amb els Desenganys de l'Apocalipsi. Hem seleccionat una mostra significativa partint de textos presentats en edicions crítiques o reprenen les publicacions d’època. Així, doncs, la difusió pública de la poesia barroca en català adquireix fórmules que s'adapten a l'espectre social del seu receptor.

Centrant-nos en el concepte de mort, s'observa una tendència lligada a les preocupacions de l'època. Els textos presentats es fan ressò dels tòpics literaris del naufragi, l'eclipsi solar, la nit o el renaixement, entre d'altres. La vanitas literària té un caràcter supranacional que podem trobar en llengua catalana. A més a més, les cites a auctoritas clàssiques i al llenguatge emblemàtic ens situen en un àmbit culte de predicació funerària en els nostres territoris. La conceptualització d'aquestes idees és un testimoni de la immersió cultural de la poesia catalana en època barroca, a la que hem d'afegir els recursos literaris, les tipologies de composicions, la mètrica o l'ús del llenguatge utilitzats.

Malgrat tractar temes d'introspecció i meditació personal sobre el final de la vida, la mostra realitzada de textos ens evoca una difusió i projecció pública. Ja sigui a través de la transmissió oral i/o escrita, la literatura esdevenia part de les festes efímeres i de les mostres col lectives en memòria dels difunts. De rerefons religiós, moltes de les produccions conservades s'atenen a un terreny cívic que lliga amb els contextos polítics en els quals es desenvolupen. Es dóna així una funció social a la poètica de la mort que hem volgut relacionar amb el moment quan es realitza i la seva connexió amb les narratives històriques i la cosmovisió dels segles XVII i XVIII. 


\section{Bibliografia}

Alegret, J. (2009) «Tots els sonets de Francesc Fontanella», dins Sansano, G. / Valsalobre, P. (eds.), Fontanellana. Estudis sobre l'època i l'obra de Francesc Fontanella (1622-1683/85), Girona, Documenta Universitaria, pp. 207-232.

Armanyà i Font, F. (1764) Oracion e inscripciones en las sumptuosas exequias que el Convento del P.S. Agustin de Barcelona dedicó en su real templo a la pia memoria de Fr. Agustin de Eura: en los dias 29 y 30 de enero de 1764, Barcelona, Juan Nadal.

Bialostocki, J. (1988) The Message of Images. Studies in the History of Art, Viena, Irsa.

Bonaventura i Ivars, M. (2006) «Imatges i paraules: el llenguatge mixt de la literatura emblemàtica en Francesc Fontanella. Un recorregut per la guerra, la pietat i la morts, dins Valsalobre, P. / Sansano, G. (eds.), Francesc Fontanella: una obra, una vida, un temps, Bellcaire d'Empordà, Edicions Vitel la, pp. 197-223.

- (2010) «L'emblemàtica commemorativa. Un gènere que abandona els llibres per incorporar-se a la bullícia de l'espai públic i de les celebracions», dins Miralles, E. (ed.), Del Cincents al Setcents. Tres-cents anys de literatura catalana, Bellcaire d'Empordà, Edicions Vitel la, pp. 401-437.

Canalda i Llobet, S. (2016) «A l'entorn dels set pecats capitals: la iconografia dels novíssims de Flandes a Catalunya», Matèria. Revista Internacional d'Art, 10-11, pp. 225-242.

Cases, M. (ed.)(1974) Desenganys del Apocalypsis, Barcelona, Curial.

Clarasó, M. / Miró, M.-M. (eds.) (2008) Panegíric a la mort de Pau Claris de Francesc Fontanella, Barcelona, Fundació Pere Coromines.

(2009) «Singularitat, modernitat i caràcter reivindicatiu del Panegíric a la mort de Pau Claris de Francesc Fontanella (1641)», dins Sansano, G. / Valsalobre, P. (eds.), Fontanellana. Estudis sobre l'època i l'obra de Francesc Fontanella (1622-1683/85), Girona, Documenta Universitaria, pp. 195-206.

Diez Borque, J. M. (1993) Verso e imagen. Del Barroco al Siglo de las Luces, Madrid, Calcografía Nacional / Dirección General de Patrimonio Cultural.

Fontanella, F. (1641) Occident, eclipse, obscuredat, funeral, aurora, claredat, belleza, gloriosa al sol, lluna y estela radiant de la esfera, del epicle, del firmament de Cathalunya: panegirica alabança, en lo vltim vale, als manes vencedors del doctor Pau, Barcelona, Gabriel Nogués.

Galindo Blasco, E. (1991) «La escritura y la imagen en las exequias de Carlos II en la catedral de Barcelona: una lectura del túmulo y de las poesías, caligramas y jeroglíficos», Cuadernos de Arte e Iconografía, IV, 7, pp. 273-283.

Gibson, W. S. (1973) «Hieronymus Bosch and the Mirror of Man: The Authorship and Iconography of the "Tabletop of the Seven Deadly Sins" ", Oud Holland, 87, pp. 205-226.

Miró, M.-M. (1995) La poesia de Francesc Fontanella, II, Barcelona, Curial, 2 vol. (1998) Francesc Fontanella, Antologia poètica, Barcelona, Editorial Curial. 
Nenias reales...1701: Nenias reales y lagrimas obsequiosas que a la immortal memoria del gran Carlos Segundo en credito de su mas imponderable dolor y desempeño de su mayor fineza dedica y consagra la Academia de los desconfiados de Barcelona las saca en su nombre à la luz publica Don Joseph Amat de Planella y Despalau, Barcelona, Rafael Figueró.

Ortiz García, J. A. (2011) «Entre novísimos y cartujos. La cultura gráfica catalana en torno a la muerte», dins Zafra, R. / Azanza, J. J. (eds.) Emblemática Trascendente. Actas del VII Congreso Internacional de la Sociedad Española de Emblemática, Pamplona, Universidad de Navarra, pp. 607617.

(2014) «L'enemiga obedient? Les exèquies reials a Catalunya en època moderna», dins Canalda, S. / Fontcuberta, C. (eds.) Imatge, devoció i identitat a l'època moderna (ss. XVI-XVIII), Barcelona, Universitat de Barcelona, pp. 157-168.

Pérez Samper, M. A. (1989) «Les festes reials a la Catalunya del barroc», dins Rossich, A. / Rafanell, A. (eds.) El barroc català, Barcelona, Edicions dels Quaderns Crema, pp. 345-377.

Rocabertí, J. (1701) Lagrimas amantes de la Excelentissima ciudad de Barcelona: con que, agradecida a las reales finezas y beneficios, demuestra su amor y su dolor en las magnificas exequias que celebrò á las amadas y venerables memorias de su difunto rey y señor don Carlos II descrivelas Ioseph Rocaberti, Barcelona, Juan Pablo Martí.

Rossich, A. / Valsalobre, P. (2006) Poesia catalana del barroc. Antologia, Bellcaire d'Empordà, Edicions Vitel la.

Sala i Berart, G. (1641) Lagrimas catalanas al entierro y obsequias del deputado ecclesiastico de Cataluña, Pablo Claris, Barcelona, Gabriel Nogués.

Silva Maroto, P. (ed.) (2016) El Bosco: la exposición del V Centenario, Madrid, Museo Nacional del Prado.

Socias, I. (1993a) «El contracte dels quatre gravats dels novíssims, entre l'impressor i gravador Joan Jolis Santjaume i Magí Casas, doctor en teologia», Pedralbes. Revista d'bistòria moderna, separata 13.

(1993b) «Els desenganys de l'Apocalipsis disposats i declarats amb els seus signes», Actes del I Congrés d'bistòria de l'església catalana des dels origens fins ara, Solsona, pp. 811-821.

Valsalobre, P. (1989) «De la dansa macabra a l'anatomia mental. A propòsit d'Agustí Eura», dins Rossich, A. / Rafanell, A. (eds.), El barroc català, Barcelona, Quaderns Crema, pp. 567-593.

- (2002) Agustí Eura. Obra poètica i altres textos, Barcelona, Fundació Pere Coromines.

Valsalobre, P. / Sogues, M. (coords.), Rossich, A., Miralles, E., Castaño, M., Garcia Busquets, A., Zaragoza, V., Figueras, N. (eds.) (2017) Francesc Fontanella, Obra poètica completa de Francesc Fontanella, edició crítica electrònica, Servei de Publicacions de la Universitat de Girona <http:// www.nise.cat/BibliotecaDigital/Autors/FrancescFontanella.aspx $>$.

Valsalobre, P. / Miralles, E. / Rossich, A. (2015) O he de morir o he d'amar. Antologia poètica de Francesc Fontanella, Barcelona, Empúries.

Vistarini, A. B. / Cull, J. T. (1999) Enciclopedia de Emblemas Españoles Ilustrados, Madrid, Akal. 